\title{
PENGARUH SUHU DALAM PEMBUATAN KARBON AKTIF DARI KULIT SALAK (Salacca edulis) DENGAN IMPREGNASI ASAM FOSFAT $\left(\mathrm{H}_{3} \mathrm{PO}_{4}\right)$
}

\author{
Muhammad Turmuzi, Arion Syaputra \\ Departemen Teknik Kimia, Fakultas Teknik, Universitas Sumatera Utara, \\ Jl. Almamater Kampus USU Medan 20155, Indonesia \\ Email : arionaritonang@gmail.com
}

\begin{abstract}
Abstrak
Penelitian ini bertujuan untuk untuk menentukan yield, bilangan iodin dan karakteristik luas permukaan pori karbon aktif dari kulit salak. Karbon aktif dibuat dengan metoda impregnasi dengan asam fosfat $\left(\mathrm{H}_{3} \mathrm{PO}_{4}\right)$. Kulit salak yang telah dihaluskan 1-2 mm direndam dengan asam fosfat selama $\left(\mathrm{H}_{3} \mathrm{PO}_{4}\right)$ dengan konsentrasi $10 \%$ selama 3 jam. Disaring dan dikeringkan selama 24 jam pada suhu $60^{\circ} \mathrm{C}$. Kulit salak yang telah diimpregnasi di pirolisis pada suhu $400-600{ }^{\circ} \mathrm{C}$ selama 1 jam. Kulit salak yang telah dipirolisis didinginkan pada desikator selama 30 menit dan dicuci hingga pH netral. Kemudian dikeringkan hingga massa konstan. Hasil penelitian menunjukkan yield terbaik yaitu pada suhu $400^{\circ} \mathrm{C} 71,70 \%$. Luas permukaan terbaik adalah $4078,694 \mathrm{~m}^{2} / \mathrm{g}$. Sedangkan bilangan iodin terbaik adalah 494,91 $\mathrm{mg} / \mathrm{g}$ pada suhu $600^{\circ} \mathrm{C}$.
\end{abstract}

Kata kunci: karbon aktif, bilangan iodin, luas permukaan, impregnasi, kulit salak

\begin{abstract}
This study was aimed to determine the yield, iodine and characteristics of activated carbon pore surface area. Activated carbon is made by impregnation method with phosphoric acid $\left(\mathrm{H}_{3} \mathrm{PO}_{4}\right)$. Snake fruit peel that has been mashed 1-2 mm soaked with phosphoric acid for $\left(\mathrm{H}_{3} \mathrm{PO}_{4}\right)$ with concentration $10 \%$ for 3 hours. Filtered and dried for 24 hours at $60{ }^{\circ} \mathrm{C}$. Snake fruit peel that has been impregnated pyrolysis at $400-600{ }^{\circ} \mathrm{C}$ for 1 hours. Snake fruit peel that has been pyrolysis cooled in a desiccator for 30 minutes and washed until neutral $\mathrm{pH}$. Then dried to a constant mass. The results showed that the best yield at a temperature of $400{ }^{\circ} \mathrm{C} 71.70 \%$. The best surface area is 4078,694 $\mathrm{m}^{2} / \mathrm{g}$. While iodine best is 494,91mg/g at a temperature $600{ }^{\circ} \mathrm{C}$.
\end{abstract}

Key words: activated carbon, iodine number, surface area, impregnation, snake fruit peel

\section{Pendahuluan}

Buangan industri merupakan sumber utama bermacam jenis polusi logam di dalam sungai [10]. Ada berbagai metode untuk menghilangkan logam berat termasuk presipitasi kimia, filtrasi membran, ion exchanger, ekstraksi cair atau elektrodialisis. Namun, metode ini tidak banyak digunakan karena biaya yang tinggi dan kelayakan yang rendah untuk industri skala kecil. Sebaliknya, teknik adsorpsi adalah salah satu metode yang disukai untuk menghilangkan logam berat karena efisiensi dan biaya rendah [6]. Adsorpsi banyak digunakan sebagai metode pemisahan fisik yang efektif untuk eliminasi atau menurunkan konsentrasi berbagai polutan terlarut (organik, anorganik) dalam limbah [2].

Buah salak (Salacca edulis) mengandung banyak jumlah senyawa nutrisi utama (serat, protein, lemak-lemak, dan karbohidrat) dan memiliki antioksidan yang tinggi. Penelitian sebelumnya menunjukkan bahwa buah salak mempengaruhi tingkat lipid plasma dan makanan yang mengandung rendah kolesterol sehingga banyak dikonsumsi [7]. Namun, limbah padat dari buah salak yaitu kulit salak masih belum banyak diolah menjadi produk yang bermanfaat oleh masyarakat setempat. Kulit salak yang masih segar atau yang baru dilepas umumnya mengandung air, karbohidrat, mineral dan protein [2]. Arang aktif dapat dibuat dari bahan yang mengandung karbon. Arang aktif adalah arang yang diproses secara fisika atau kimia sehingga mempunyai daya serap/adsorpsi yang tinggi. Karbonisasi adalah proses pemecahan/penguraian selulosa menjadi karbon pada suhu berkisar $275{ }^{\circ} \mathrm{C}$. Dalam aktifasi kimia, hal pertama yang dilakukan yaitu impregnasi dengan zat aktifasi misalnya $\mathrm{H}_{3} \mathrm{PO} 4$, $\mathrm{KOH}, \mathrm{K}_{2} \mathrm{CO}_{3}, \mathrm{H}_{2} \mathrm{SO}_{4}, \mathrm{Na}_{2} \mathrm{CO}_{3}, \mathrm{NaOH}, \mathrm{NaCl} \mathrm{HCl}$, $\mathrm{H}_{2} \mathrm{SO}_{4}, \mathrm{CaCl}$ dan $\mathrm{ZnCl}_{2}$ [3,4]. Aktivasi adalah perubahan secara fisik dimana luas permukaan dari karbon meningkat dengan tajam dikarenakan 
terjadinya penghilangan senyawa tar dan senyawa sisa-sisa pengarangan [23].

\section{Teori}

Buah salak (Salacca zalacca Reinw) berasal dari Asia Tenggara. Buah salak berbentuk seperti telur dan kulit buah berwarna coklat. Buah seperti nanas, buah per dan aroma seperti pisang. Salak (Salacca zalacca) merupakan salah satu jenis buah yang paling penting di Indonesia. Salak mempunyai berat hingga $70 \mathrm{~g}$ pada tahap pematangan. Buah salak mengandung tiga bagian pada biji mencakup dengan daging putih. Sebagian besar buah salak dikonsumsi dengan segar dan beberapa diolah menjadi jus, buah kaleng dan selai [6]. Buah Salak adalah spesies pohon palem (keluarga Arecaceae) asli Indonesia dan Malaysia. Buah tumbuh dalam kelompok di dasar telapak tangan, dan juga dikenal sebagai salak karena kulit bersisik coklat kemerahan. Ada sekitar 18 varietas Salak sedang dikembangkan di tingkat komersial di Indonesia [19].

Secara umum proses pembuatan karbon aktif terdiri dari proses fisika dan kimia. Aktivasi fisika terdiri dari 2 tahap; (I) Karbonisasi: Material dengan kandungan karbon yang di pirolisis pada suhu antara $600-900{ }^{\circ} \mathrm{C}$, tanpa oksigen (biasanya dalam suasana inert dengan gas seperti argon atau nitrogen). (II) Aktivasi/ Oksidasi: bahan baku atau bahan yang telah dikarbonisasi dioksidasi atmosfer (karbon monoksida, oksigen, atau steam) pada suhu di atas $250{ }^{\circ} \mathrm{C}$, biasanya dalam kisaran suhu 600-1200 ${ }^{\circ} \mathrm{C}$ [11]. Dalam aktivasi kimia, bagian paling penting adala impregnasi dengan zat kimia diantaranya zink klorida $(\mathrm{ZnCl})$, Kalium hidroksida $(\mathrm{KOH})$, dan asam fosfat $\left(\mathrm{H}_{3} \mathrm{PO}_{4}\right)$ [14].

Karbon berpori merupakan karbon dalam bentuk amorf yang mempunyai luas permukaan yang besar dan daya serap yang tinggi. Luas permukaan merupakan sifat fisis yang paling penting dari karbon berpori, sehingga memungkinkan dijadikan sebagai bahan adsorben. Gambar 1 menunjukkan struktur karbon aktif Material ini dibuat dari pirolisis prekursor karbon organik, polimer alam maupun polimer sintetis yang kemudian diaktifkan untuk memperbesar surface areanya [19]. Table 1 merupakan standar mutu karbon aktif. Faktor-faktor yang mempengaruhi proses karbonasi :

\section{Waktu karbonisasi}

Bila waktu karbonisasi diperpanjang maka reaksi pirolisis semakin sempurna sehingga hasil arang semakin turun tetapi cairan dan gas makin meningkat. Waktu karbonisasi berbeda-beda tergantung pada jenis-jenis dan jumlah bahan yang diolah.

2. Suhu karbonisasi

Suhu karbonisasi yang berpengaruh terhadap hasil arang karena semakin tinggi suhu, arang yang diperoleh makin berkurang tapi hasil cairan dan gas semakin meningkat. Hal ini disebabkanoleh makin banyaknya zat-zat terurai dan yang teruapkan [3].

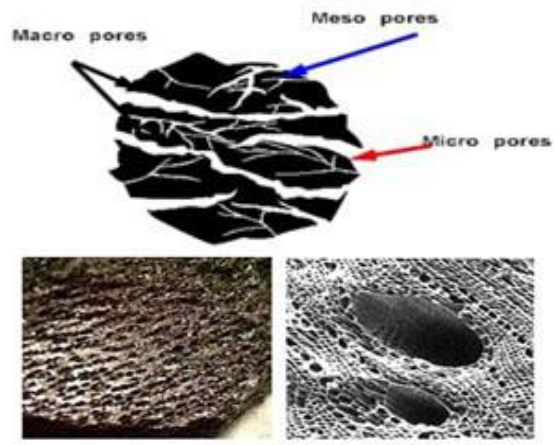

Gambar 1. Struktur Karbon Aktif [17]

Tabel 1. Standar Mutu Karbon Aktif [1,13]

\begin{tabular}{|l|c|c|}
\hline \multirow{2}{*}{\multicolumn{1}{|c|}{ Uraian }} & \multicolumn{2}{c|}{ Persyaratn Kualitas } \\
\cline { 2 - 3 } $\begin{array}{l}\text { Bagian yang } \\
\text { hilang pada } \\
\text { pemanasan } 950^{\circ} \mathrm{C}\end{array}$ & Matiran & Serbuk \\
Konsentrasi air & Maks. 4,5\% & Maks. 25\% \\
Konsentrasi abu & Maks. 2,5\% & Maks. 15\% $15 \%$ \\
Daya serap & $\geq 760 \mathrm{mg} / \mathrm{g}$ & $\geq 760 \mathrm{mg} / \mathrm{g}$ \\
terhadap larutan $\mathrm{I}_{2}$ & $300-3500$ & $300-3500$ \\
Luas permukaan & $\mathrm{m}^{2} / \mathrm{g}$ & $\mathrm{m}^{2} / \mathrm{g}$ \\
\hline
\end{tabular}

\section{Metodologi Penelitian \\ Bahan dan Alat}

Bahan yang digunakan adalah kulit salak yang berasal dari Kabupaten Tapanuli Selatan, asam fosfat $\left(\mathrm{H}_{3} \mathrm{PO}_{4}\right)$, metilen biru, iodin, natrium tiosulfat, dan amilum. Alat utama yang digunakan adalah tungku, tabung dan gas nitrogen, water bath, blender, erlenmeyer, refluks kondensor dan Beaker glass.

\section{Proses Aktivasi Kulit Salak}

Kulit salak yang diperoleh dari Kabupaten Tapanuli Selatan dicuci dengan air dan kemudian dikeringkan. Kulit salak yang telah di haluskan dengan ukuran 1-2 mm dan dikeringkan. Sebanyak 150 gram kulit salak yang telah kering direndam dalam asam fosfat $\left(\mathrm{H}_{3} \mathrm{PO}_{4}\right)$ dengan konsentrasi $10 \%$ selama 3 jam pada suhu $85{ }^{\circ} \mathrm{C}$. Kemudian disaring dan dikeringkan di dalam oven pada suhu $60{ }^{\circ} \mathrm{C}$ selama 24 jam. Kulit salak ditimbang sebanyak 12 gram dan di pirolisis selama 1 jam pada suhu $400-600{ }^{\circ} \mathrm{C}$. Kemudian dicuci hingga $\mathrm{pH}$ netral dengan air destilat pada suhu $85^{\circ} \mathrm{C}$ [17].

\section{Penentuan Bilangan Iodin}

Sebanyak 0,5 gram sampel ditimbang dan dimasukkan ke dalam erlenmeyer. Kemudian ditambahkan larutan iodin 0,1N $25 \mathrm{~mL}$ dan diaduk 
selama 15 menit lalu disaring. Sebanyak $10 \mathrm{~mL}$ filtrate dititrasi dengan larutan natrium tiosulfat $\left(\mathrm{Na}_{2} \mathrm{~S}_{2} \mathrm{O}_{3}\right)$ 0,1N hingga berwarna kuning muda. Kemudian ditambahkan amilum $1 \%$ pada larutan dan titrasi dilanjutkan hingga warna biru hilang. Daya serap iodin dapat ditentukan dengan persamaan sebagai berikut [18]:

$$
\text { DSI }=\frac{\left(\mathrm{V}-\frac{\mathrm{TxC}_{1}}{\mathrm{C}_{2}}\right) \mathrm{xW}_{1} \times \mathrm{Fp}}{\text { gr sampel }}
$$

DSI=daya serap iodin $(\mathrm{mg} / \mathrm{g}), \mathrm{V}=$ filtrat yang dititrasi $(10 \mathrm{~mL}), \mathrm{T}=$ volume titrasi $\mathrm{Na}_{2} \mathrm{SO}_{3} \mathrm{~N}, \mathrm{C}_{1}$ $=$ konsentrasi $\mathrm{Na}_{2} \mathrm{SO}_{3} \mathrm{~N}, \mathrm{C}_{2}=\operatorname{konsentrasi} \operatorname{iod}(\mathrm{N})$, $\mathrm{W}_{1}=$ berat $\operatorname{iod}(12,69 \mathrm{mg} / \mathrm{L})$.

\section{Penentuan Daya Serap Metilen biru}

Dalam penelitian ini, metilen biru dipilih dalam riset ini karena telah diketahui kekuatan adsorpsi pada padatan dan dikenal kegunaannya dalam karakterisasi adsorpsi material [9]. Kalibrasi metilen biru dilakukan dengan konsentrasi 20-200 ppm pada panjang gelombang 668nm. Kemudian Sebanyak 0,1 gram karbon aktif direndam dalam metilen biru selama 24 jam dan diaduk kemudian disaring. Filtrat diukur absorbansinya dengan panjang gelombang $668 \mathrm{~nm}$. Luas permukaan dapat dihitung dengan persamaan berikut;

$$
\mathrm{S}=\frac{\mathrm{X}_{\mathrm{m}} \cdot \mathrm{N} \cdot \mathrm{a}}{\mathrm{Mr}}
$$

$\mathrm{S}=$ luas permukaan adsorben $\left(\mathrm{m}^{2} / \mathrm{g}\right), \mathrm{N}=$ bilangan Avogrado $\left(6,002 \times 10^{-2} \mathrm{~mol}^{-1}\right), \mathrm{X}=$ berat adsorbat teradsorpsi $(\mathrm{g} / \mathrm{g}), \mathrm{a}=$ luas penutupan oleh 1 molekul metilen biru $\left(197 \times 10^{-20} \mathrm{~m}^{2}\right), \mathrm{Mr}=$ massa molekul relatif metilen biru $(320,5 \mathrm{~g} / \mathrm{mol})$ [9].

\section{Hasil dan Pembahasan \\ Pengaruh Suhu terhadap yield}

Suhu dapat memberikan pengaruh aktivasi yang lebih besar terhadap yield karbon dan adsorpsi. Pada gambar 2 menunjukkan pengaruh suhu terhadap yield.

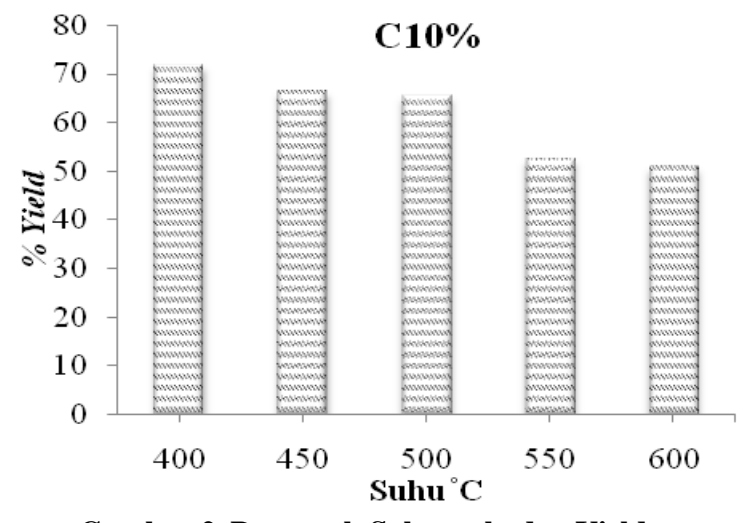

Gambar 2. Pengaruh Suhu terhadap Yield

Hasil penelitian menunjukkkan nilai yield yang diperoleh pada suhu $400-600{ }^{\circ} \mathrm{C}$ yaitu 71,70
50,82\%. Menurut Legrouri., dkk (2012) bahwa semakin meningkatnya suhu aktivasi, maka yiled yang dihasilkan semakin menurun. Suhu aktivasi berbanding terbalik dengan yield[11]. Pada suhu aktivasi yang lebih tinggi, pengurangan zat volatil menjadi lebih besar sehingga hasil padatan yang diperoleh lebih sedikit [21].

\section{Pengaruh Suhu terhadap bilangan iodin}

Bilangan iodin merupakan parameter dasar paling penting digunakan untuk karakterisasi karbon aktif. iodin merupakan ukuran pada tingkat keaktifannya. Bilangan iodin dapat digunakan sebagai pendekatan untuk luas permukaan dan mikropori karbon aktif dengan presisi yang baik [20]. Suhu karbonisasi mempunyai pengaruh yang signifikan pada pembentukan pori karbon aktif [8]. Pada gambar 3 dibawah ini menunjukkan pengaruh suhu terhadap bilangang iodin.

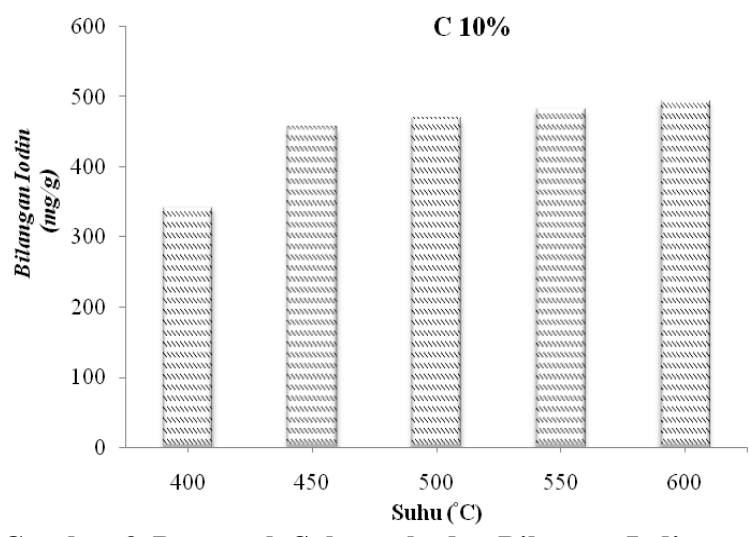

Gambar 3. Pengaruh Suhu terhadap Bilangan Iodin

Hasil penelitian ini menunjukkan nilai iodin semakin meningkat dengan meningkatnya suhu karbonisasi. Bilangan iodin terendah adalah $342,63 \mathrm{mg} / \mathrm{g}$ sedangkan bilangan iodine tertinggi adalah 494,91mg/g. Menurut Wang., dkk (2010) semakin tinggi suhu dan waktu aktifasi maka semakin tinggi bilangan iodin karena makin banyak permukaan karbon yang teraktifasi [22]

\section{Pengaruh Suhu terhadap luas permukaan}

Laju pemanasan, perbandingan impregnasi dan suhu aktivasi merupakan kondisi yang sensitife dalam pembentukan lingkungan luas permukaan [15]. Luas permukaan diukur dari lapisan monolayer dari standar adsorbat, kemudian nilai numeriknya didapat dari densitas adsorbat dan dimensi molekul [12]. Kemampuan adsorpsi suatu adsorben dapat diketahui dengan cara membandingkan luas permukaannya. Pada gambar 4 menunjukkan pengaruh suhu terhadap luas permukaan. 


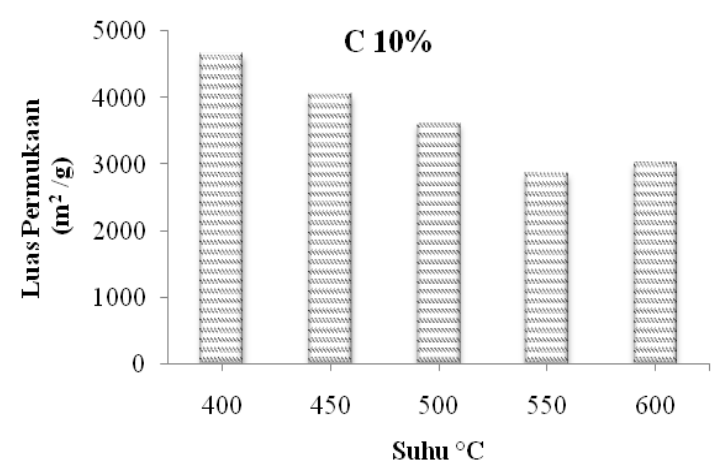

Gambar 4. Pengaruh Suhu terhadap Luas Permukaan

Hasil analisa menunjukkan semakin tinggi suhu maka luas permukaan semakin menurun. Luas permukaan terendah adalah $2984,528 \mathrm{~m}^{2} / \mathrm{g}$ dan luas permukaan paling besar adalah $4078,694 \mathrm{~m}^{2} / \mathrm{g}$. Seiring dengan meningkatnya suhu aktivasi, maka luas permukan akan semakin meningkat dan jika telah mencapai titik optimum maka luas permukaan akan menurun.[4,10]. Namun, pada percobaan ini, luas permukaan ada yang menurun. Hal ini mungkin disebabkan oleh pori semakin luas dan dapat merusak dinding antar pori sehingga menurunkan porositasnya dan terbakar dibawah suhu radiasi yang lebih tinggi [23].

\section{Kesimpulan}

Hasil yang diperoleh pada penelitian ini yaitu semakin tinggi suhu maka yield semakin menurun. Yield terbesar yaitu pada suhu $400{ }^{\circ} \mathrm{C}$ sebesar $71,70 \%$. Semakin tinggi suhu maka daya serap terhadap Iodin dan luas permukaan semakin baik. Hasil karbon aktif terbaik berada pada $600{ }^{\circ} \mathrm{C}$ yaitu daya serap terhadap iodin sebesar $494,91 \mathrm{mg} / \mathrm{g}$, luas permukaan terbaik adalah $4078,694 \mathrm{~m}^{2} / \mathrm{g}$.

\section{DAFTAR PUSTAKA}

[1] Asbahani, Pemanfaatan Limbah Ampas Tebu Sebagai Karbon Aktif Untuk Menurunkan Kadar Besi Pada Air Sumur Jurnal Teknik Sipil Untan, Vol. 13 No. 1 JUNI 2013: hal. 105-114

[2] Chaiyut. A. Buasri, N, V. Loryuenyong, E. Phakdeepataraphan, S. Watpathomsub, dan V., Kunakemakorn. Synthesis of Activated Carbon Using Agricultural Wastes from Biodiesel Production, International Journal of Chemical, Nuclear, Metallurgical and Materials Engineering Vol:7 No:1, 2013

[3] Elly Kurniati, Pemanfaatan Cangkang Kelapa Sawit Sebagai Arang Aktif, Jurnal Penelitian Ilmu Teknik Vol.8, No.2 Desember 2008 : hal 96-103

[4] Foo P.Y.L dan Lee L.Y. Preparation of Activated Carbon from Parkia Speciosa Pod by Chemical Activation. Vol II 2078-0958 2010 : hal. 34-37

[5] Gorinstein, Shela, Ratiporn Haruenkit, Sumitra Poovarodom, Yong-Seo Park, Suchada Vearasilp, Milan Suhaj, Kyung-Sik Ham, Buk-Gu Heo, Ja-Yong Cho, Hong Gi Jang. The comparative characteristics of snake and kiwi fruits Food and Chemical Toxicology, Vol. 472009 : hal. 1884-1891

[6] Habib, Ahsan, Nazrul Islam, Anarul Islam and A. M. Shafiqul Alam. Removal of Copper from Aqueous Solution Using Orange Peel, Sawdust and Bagasse. Pak. J. Anal. Environ. Chem.; Vol. 8, No. 1 \& 2. 2007

[7] Hendri, Zulfi, M.Sn dan Arianingrum, Retno, M.Si, Penerapan Teknologi Pemanfaatan Kulit Salak Pada Produk Keramik Guna Peningkatan Usaha Kerajinan Keramik Di Kecamatan Jetis, Kabupaten Bantul, 2010. Universitas Negeri Yogyakarta.

[8] Hernandez. Joan Rollog, Sergio C Capareda, dan Froilan L. Aquino. Activated Carbon Production From Pyrolysis And Steam Activation Of Cotton Gin Trash. Beltwide Cotton Conferences, New Orleans. 2007.

[9] Kaewprasit, Chongrak, Eric Hequet, Noureddine Abidi, and Jean Paul Gourlot, Quality Measurements Application of Methylene Blue Adsorption to Cotton Fiber Specific Surface Area Measurement: Part I. Methodology, The Journal of Cotton Science, Vol. 2 (1998) :164-173

[10] Kwaghger, A dan Ibrahim J.S. Optimization of Conditions for the Preparation of Activated Carbon from Mango Nuts using $\mathrm{HCl}$. American Journal of Engineering Research (AJER). Volume-02. Issue-07. 2013; hal. 74-85

[11] Legrouri. K., M. El Harti, M. Oumam, E. Khouya, R. Wahbi, H. Hannache dan A. Zarrouk. Characterization And Evaluation Performance Of Activated Carbon Prepared From Coconut Shell Argan. Journal Of Chemical And Pharmaceutical Research, Vol. 4(12), 2012.

[12] Lyle F. Albright, (2009), “Albright's Chemical Engineering Handbook", USA, CRC Pres

[13] Marsh. Harry "Activated Carbon", Elsevier Science \& Technology Books, Sanfransisco, (2006), hal.121

[14] Okeola. O.F, E.O. Odebunmi dan O.M. Ameen, Comparison Of Sorption Capacity And Surface Area Of Activated Carbon Prepared From Jatropha Curcas Fruit 
Pericarp And Seed Coat, Bull. Chem. Soc. Ethiop, 26(2) 2012 : hal 137-142

[15] Patil B. S dan K. S. Kulkarni Development Of High Surface Area Activated Carbon From Waste Material. International Journal Of Advanced Engineering Research And studies. Vol. I. 2002

[16] Sahira, Joshi, Adhikari Mandira, Pokharel Bhadra Prasad and Pradhananga Raja Ram, Effects of Activating Agents on the Activated Carbons Prepared from Lapsi Seed Stone, Research Journal of Chemical Sciences, ISSN 2231-606X ; Vol. 3(5) 2013: hal. 19-24

[17] Saksule, Ashish S., Pallavi A. Kude, Adsorbents From Karanja Seed Oil Cake and Applications, International Journal Of Chemical Engineering And Applied Sciences, ISSN 2278 -1366 Vol. 2 (13). 2012: hal 13-25

[18] Suhendarwati, Lina, Bambang Suharto, dan Lillya Dewi Susanawati, Pengaruh Konsentrasi Larutan Kalium Hidroksida pada Abu Dasar Ampas Tebu Teraktivasi, Jurnal Sumberdaya Alam dan Lingkungan, Vol. 19, 2012

[19] Sukewijaya, M, N. Rai and M.S. Mahendra, Development of salak bali as an organic fruit, As. J. Food Ag-Ind. ISSN 1906-3040. 2009
[20] Srisa-Ard Samarn. Preparation Of Activated Carbon From Sindora Siamensis Seed And Canarium Sublatum Guillaumin Fruit For Methylene Blue Adsorption. International Transaction Journal Of Engineering, Management, \& Applied Sciences \& Technologies. Vol. 5 No.4. 2014.

[21] Titus. Yilleng Moses, Ochigbo Victor, Nwankwere Emeka Thompson, Sunday Moses, Nwadiogbu Onyebuchi Joseph, Kagbu James A. dan Gimba Casimire Emmanuel. Adsorption Of Carbofuran On Granulated Activated Carbon From Canaruim Schweinfurthii Seed Shell. International Journal of Scientific \& Engineering Research, Volume 4, 2013.

[22] Wang, Jun, Fu-An, Meng Wang, Ning Oiu, Yao Liang, Shui-Qiu Fang, dan Xing Jiang, Preparation Of Activated Carbon From A Renewable Agricultural Residu Of Pruning Mulberry Shoot, African Journal Of Biotechnology, Vol. 9 (19). 2010

[23] Zhong, Zhuo-Ya, Qi Yanga, Xiao-Ming Li, Kun Luo, Yang Liua, Dan Guang-Ming Zeng. Preparation Of Peanut Hll-Based Activated Carbon By Microwave-Induced Phosphoric Acid Activator And Its Application In Remozal Brilliant Blue R Adsorption, Elsevier, Vol. 2012: Hal. 17818 